\title{
Paraneoplastic syndromes associated to Hodgkin's lymphoma
}

\author{
Javier Munoz, ${ }^{1}$ Wilfredo Romero, ${ }^{2}$ Amr Hanbali, ${ }^{1}$ Philip Kuriakose ${ }^{1}$ \\ ${ }^{1}$ Haematology-Oncology Department, Henry Ford Hospital, Detroit, Michigan, USA; \\ Internal Medicine Department, Henry Ford Hospital, Detroit, Michigan, USA
}

Correspondence to Dr Javier Munoz, Jlmunoz@mdanderson.org

\section{DESCRIPTION}

A 35-year-old male with no prior medical history presented to the emergency department with fever, fatigue, mental status changes and gait disturbances over 2 months. Laboratory testing revealed pancytopenia with negative infectious investigation. CT scan of the chest and abdomen revealed splenomegaly with multiple intrathoracic and intraabdominal enlarged lymph nodes with the largest being a $5.8 \mathrm{~cm}$ periportal nodal mass. An excisional lymph node biopsy was positive for nodular sclerosis Hodgkin's lymphoma (HL) with Reed-Sternberg cells (figure 1A) and CD30 positivity (figure 1B). An atypical lymphoid infiltrate compatible with classical HL was found on bone marrow biopsy (figure 1C) confirming stage IV-B of disease. MRI of the brain revealed multiple periventricular, subcortical, pons and cerebellum T2/fluid attenuated inversion recovery hyperintensities suspicious for demyelinating disease (figure 1D). Cerebrospinal fluid studies were negative for presence of malignant cells and oligoclonal banding. A pretreatment resting radionuclide ventriculogram (RVG) showed global hypokinesia with left ventricular ejection fraction estimated to be $35 \%$ and there was no valvular disease per echocardiography. Further investigation did not reveal an obvious aetiology for the dilated cardiomyopathy. ${ }^{1}$ Anthracycline-based therapy was deemed too cardiotoxic, therefore he was treated with modified (bleomycin, etoposide, doxorubicin, cyclophosphamide, vincristine, procarbazine and prednisone) without doxorubicin, achieving complete resolution of the presenting symptoms. Two months later, subsequent RVG scan revealed improvement in his ejection fraction to $46 \%$. Follow-up MRI of the brain showed persistent demyelinating lesions with complete clinical resolution of his neurological symptoms. ${ }^{2}{ }^{3} \mathrm{He}$ remained asymptomatic and achieved complete remission per positron emission tomography scan after completion of eight cycles of chemotherapy.
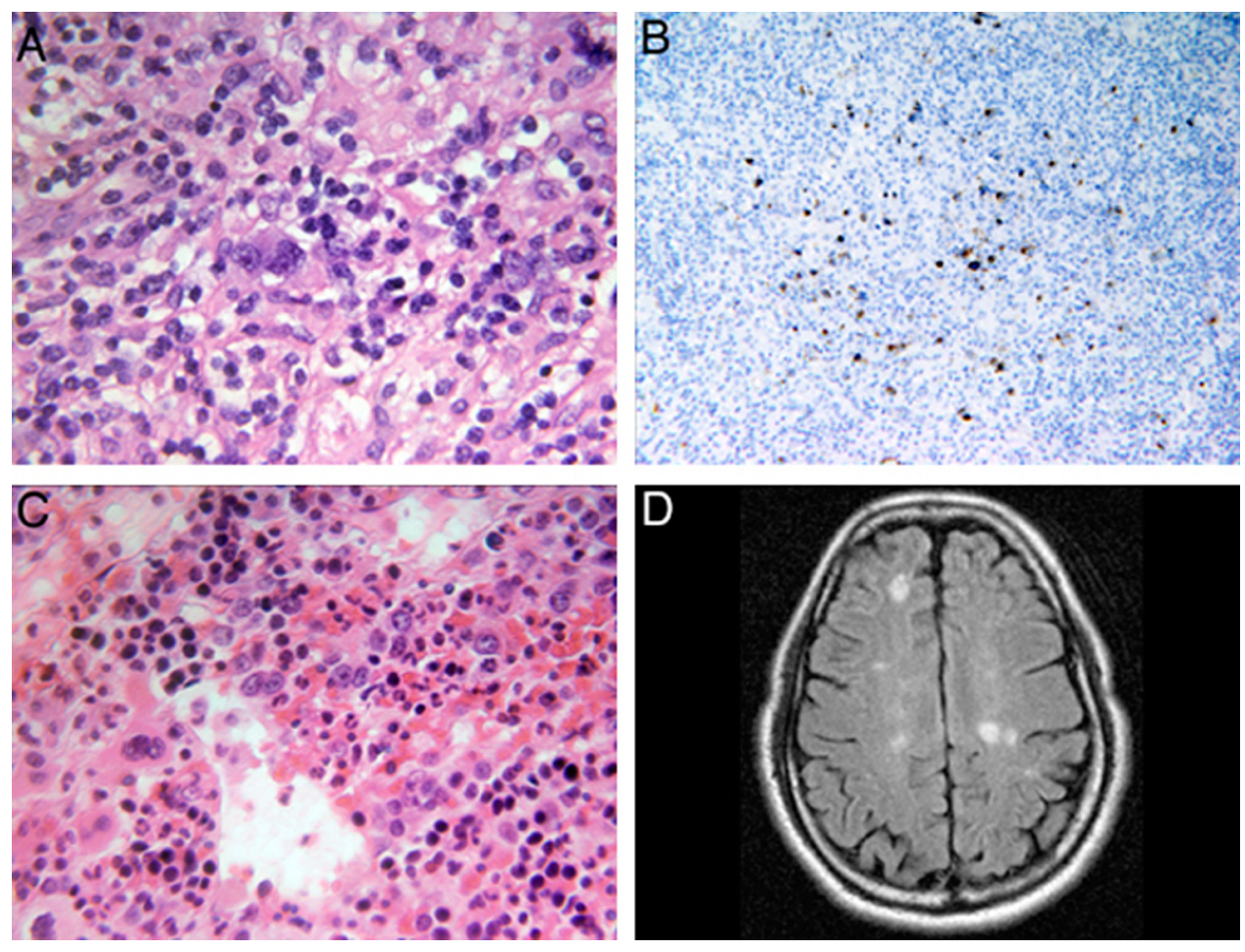

Figure 1 Excisional lymph node biopsy was positive for nodular sclerosis Hodgkin's lymphoma (HL) with Reed-Sternberg cells $(A)$ and CD30 positivity (B). An atypical lymphoid infiltrate compatible with classical HL was found on bone marrow biopsy (C) confirming stage IV-B of disease. MRI of the brain revealed multiple periventricular, subcortical, pons and cerebellum T2/fluid attenuated inversion recovery hyperintensities suspicious for demyelinating disease (D). 


\section{BMJ Case Reports}

\section{Competing interests None.}

Patient consent Not obtained.

\section{REFERENCES}

1. Thomas L, Wright J, Vajpayee N, et al. Hodgkin's disease complicated by cardiomyopathy in two young adults. Am J Hematol 2007;82:498-9.
2. Werbrouck B, Meire V, De Bleecker JL. Multiple neurological syndromes during Hodgkin lymphoma remission. Acta Neurol Belg 2005:105:48-50.

3. Habek M, Brinar WV, Hajnsek S. The association of multiple sclerosis and Hodgkin's disease: the role of Epstein-Barr virus infection. Mult Scler 2008;14:284-7.

This pdf has been created automatically from the final edited text and images.

Copyright 2011 BMJ Publishing Group. All rights reserved. For permission to reuse any of this content visit http://group.bmj.com/group/rights-licensing/permissions.

BMJ Case Report Fellows may re-use this article for personal use and teaching without any further permission.

Please cite this article as follows (you will need to access the article online to obtain the date of publication).

Munoz J, Romero W, Hanbali A, Kuriakose P. Paraneoplastic syndromes associated to Hodgkin's lymphoma. BMJ Case Reports 2011;

10.1136/bcr.10.2011.4962, Published XXX

Become a Fellow of BMJ Case Reports today and you can:

- Submit as many cases as you like

Enjoy fast sympathetic peer review and rapid publication of accepted articles

- Access all the published articles

- Re-use any of the published material for personal use and teaching without further permission

For information on Institutional Fellowships contact consortiasales@bmjgroup.com

Visit casereports.bmj.com for more articles like this and to become a Fellow 